\title{
Globalisation versus the European Social Model? Deconstructing the Contradiction Between Globalisation and the Welfare State
}

\author{
GEORG VOBRUBA* \\ Institute of Sociology, University of Leipzig
}

\begin{abstract}
Both the economic mainstream and the public debate address globalisation and welfare states as strictly contradicting one other. In contrast to this view the article points out that there exists a globalisation dilemma: globalisation both endangers and requires the welfare state. How can this dilemma be solved? This question leads to an assessment of the degree to which globalisation in fact undermines the welfare state and to the question of what strategies for social policy might alleviate the social costs of globalisation, hence absorbing the opposition to it.
\end{abstract}

Sociologický časopis/Czech Sociological Review, 2004, Vol. 40, No. 3: 261-276

\section{Introduction}

The dominant public interpretation of globalisation has changed. There is now a growing body of literature offering advice on how to challenge globalisation in everyday life, predicting the 'irresistible rise of global anticapitalism' and issuing the ominous warning 'we are everywhere' [Notes from Nowhere 2003; Roddick 2001]. Mirroring this, there are also growing numbers of statements, articles and books endeavouring to provide counter-arguments in globalisation's favour [cf. Norberg 2003; World Bank 2002]. Globalisation has found itself on the defensive. What happened?

Globalisation has turned from being a material constraint into a 'hate-term', mutating from its role of describing an unavoidable tendency occurring within capitalism into a symbol of a conspiracy of the elites against the people. It surfaced out of pure economic logic and turned into a subject at the centre of political decisions and conflicts. That it is possible to oppose globalisation has become clearly visible. The perception thus currently gaining ground is that globalisation not only is a danger, but also is in danger.

\footnotetext{
* Direct all correspondence to: Prof. Dr. Georg Vobruba, Institute of Sociology, University of Leipzig, Beethovenstrasse 15, D-04107 Leipzig, Germany, e-mail: vobruba@rz.uni-leipzig.de

(C) Institute of Sociology, Academy of Sciences of the Czech Republic, Prague 2004
} 


\section{Two brief terminological remarks}

First, what is economic globalisation? Most definitions of the concept focus on different aspects of the 'intensification' of 'worldwide' relationships [cf. Giddens 1990: 64; Held et al. 1999: 14f.; Keohane 2003: 130]. As such, economic globalisation must be defined as the intensification of economic exchange and competition by means of the worldwide spread of markets for goods, services, capital and labour. But by focusing exclusively on institutional matters this definition fails to pay enough attention to the fact that globalisation is a publicly interpreted fact. It misses the character of globalisation as a social construction with political consequences.

Consequently, any proper definition should meet the following requirements: It must focus on the perspective of institutional change; it must provide an opportunity to link this perspective with individual and collective actions, either as causes or as consequences of this change; and it must refer to the public use of the term and its effects [cf. Therborn 2001: 450]. The social sciences must deal with globalisation as a practical social construction, a fact that requires making second order observations: social scientists must be able to observe how the relevant actors observe. For this reason I propose a two-level approach to globalisation. I define economic globalisation as the intensification of economic exchange and competition, which leads to an intensified interdependency between distant living circumstances, spurring the growing entanglement of interests, of which people worldwide become increasingly aware.

Second, how to conceptualise the European social model? This too must be elaborated at two levels. At one level a description is required of the institutions that typically enable the patterns of action characteristic of the European social model. But why is this a basic requirement? If we agree that explaining institutional social change means referring to individual action - which itself is framed by institutions - then the impact of globalisation on a social model must eventually focus on the micro-foundation of the nexus between globalisation and national institutions. Thus the question is: how does globalisation influence institutions and consequently also characteristic patterns of action. At the second level it is necessary that one take into account that constructing a European social model is not just an academic affair. At least to some degree, political and social actors within society themselves think and speak of a European social model, identifying with it and linking certain consequences to it. "The European Social Model, [is] characterized in particular by systems that offer a high level of social protection, by the importance of social dialogue and by services of general interest covering activities vital for social cohesion..." ${ }^{1}$ When we speak of a European social model then, we are again in the realm of second order observations. As a consequence, there are two basic strands of research: one is to describe the main characteristics of the European social model, the-

${ }^{1}$ European Social Agenda. In: Presidency Conclusions: Nice European Council Meeting, 7-9 December 2000. [Quoted from Vaughan-Whitehead 2003: 4] 
orising about their interrelations and pointing out their consequences; the second is to raise the empirical question of whether the relevant actors make reference to a European social model, how they describe it, what they attribute to it, and how they act according to their understanding of it.

Notwithstanding the huge organisational variety, state-provided social security is - and is seen as - a common institutional feature in Europe [cf. Gough 1997]. Social security has a critical impact on individual action: it reduces the unpredictability of an individual's future with respect to one of its most important dimensions - the material preconditions of individual existence. By mitigating immediate economic constraints it provides a certain long-term perspective for individual action [cf. Vobruba 1991]. In this respect, European welfare states contribute to a certain long-term orientation built into the European social model [compared to the US; cf. Vobruba 2001]. Social security reduces constraints and provides people with additional room to manoeuvre in.

In this paper I shall argue that this impact social security has on individual action is crucial for the capacity of the European Social Model to cope with globalisation - and vice versa: economic globalisation crucially depends on the welfare state's capacity to absorb 'its discontents' [Stiglitz 2002]. Globalisation needs to be protected against itself.

\section{Globalisation: A historical trend that might be interrupted}

The idea of globalisation and the notion of where it takes place - the 'world society' - are as old as modernity itself. The term first came into use as a normative orientation within philosophical discourse. Kant was able to present his 'weltbürgerliche Absicht' [Kant 1912-23] as an optimistic moral project, just like 'proletarian internationalism'. The emergence and development of capitalism led to the process whereby world-society was realised. Thus, the normative idea of a world-society came to be accompanied by real-globalisation. Not very surprisingly, real-globalisation distorted the central normative hopes of the idea of a world-society, as realglobalisation did not at all lead to a global community, implying a potential for global solidarity, but rather triggered new conflicts of interests. "So gab es denn eine Weltgeschichte und ihre populären Deutungsmuster, die nicht mehr auf die Welt paßten, und eine Praxis globaler Integration, die unerklärt blieb." [Bright and Geyer 1994: 16] Economic globalisation is neither something entirely new, nor has it developed with extraordinary speed. It is also important to note that what we are now facing is the second wave of globalisation within the development of capitalism - following the severe decline of the first and several decades of nationalistic isolationism in between [cf. Borchardt 2001].

Hirst and Thompson [1996] collected data in an effort to describe the processes involved in the transnationalisation of national economies since the 19th century. If the volume of foreign trade is taken as an indicator, it is possible to see that 
transnationalisation was steadily increasing up until the beginning of the First World War. It stagnated between 1913 and 1929, and broke down over the course of the world economic crisis [cf. Held et al. 1999: 157]. It was not until the end of the Second World War that world trade began to recover [cf. Hirst and Thompson 1996: 22]. The 'relative openness' of important national economies, defined as the volume of foreign trade (exports plus imports) in percentages of GDP, has steadily increased since 1950, but not with spectacular speed. In 1973 it was still on a level lower than in 1913 [Hirst and Thompson 1996: 27, 28; cf. Yeates 2001: 35].

Data on migration to the United States - the world's most important migration destination - reveal features similar to the data on trade. Since the end of the 19th century migration has rapidly increased, both in absolute numbers and in relation to the population in the United States. At the time of the First World War migration reached its absolute peak and then declined dramatically between the wars. Not until the middle of the 1950s did migration rise again, but in absolute numbers, as well as in the percentage of population migration to the United States, it is far from attaining the dimensions it possessed in the first two decades of the 20th century [Hirst and Thompson 1996: 26].

Although foreign trade is still an important force in transnationalisation [cf. Nofal 1996], since the 1960s it has been increasingly superseded by foreign direct investments (FDIs). One emerging feature is that the volume of worldwide foreign trade is increasing faster than GDP, and foreign direct investments are increasing faster than the volume of foreign trade. Foreign investments are supplanting foreign trade as the main force in economic transnationalisation [cf. Hirst and Thompson 1996: 54, 55; Messner 1997: 134]. Compared with foreign trade, the significance of the rapidly growing volume of FDIs lies in the fact that they are more likely to endanger the autonomous space for political manoeuvring and that they are more difficult to regulate.

Foreign direct investments are highly concentrated processes in a two fold sense. First, one-third of all FDI stocks are under the control of no more than 100 multinational companies [Hirst and Thompson 1996: 53]. Second, the lion's share of all FDIs flow from highly developed countries to highly developed countries [cf. Yeates 2001: 37]. Thus, the observation of globalisation in a long-term historical perspective draws attention to three important points:

1. Not just theoretical arguments but also empirical evidence exist to indicate that globalisation is a tendency inherent to capitalism. In the very long run, globalisation seems to be a steady economic trend in the modern capitalist world society, but it can be interrupted.

2. Though globalisation was never, in its history, an automatism, but rather was spurred on by political decisions, this feature has nevertheless become more visible to the public owing to several basic decisions and treaties (NAFTA, EU, MERCOSUR) which have been reached in the recent past.

3. Even if, with regard to individual countries, the process of globalisation may be unavoidable, in the short run it can be evaded. Participation and non-participa- 
tion in globalisation have causes and consequences that can be anticipated and are subject to political calculi and decisions. These features are of crucial importance for the analysis of new qualities in the current processes of globalisation, and in particular for assessing the impact on national welfare states. Later I shall come back to the question of whether globalisation undermines welfare states.

\section{Political decisions in the globalisation process}

Participation in the globalisation process ushers in the pressures of modernisation. Rapidly progressing processes of modernisation or transformation give rise to costs that are distributed unequally among people and over time. The unequal distribution of the costs of modernisation among people means that this creates winners and losers. The unequal distribution of costs over time means that in the short run there are more costs, whilst in the long run more gains. What is more, it is almost clear who the bearers of the costs are, whilst the gains appear in a more diffused manner.

Roughly speaking, it is possible to distinguish the following four possible types of participants in the globalisation process:

1. Short-term and long-term winners: they support participation in the globalisation process.

2. Short-term winners who became long-term losers: they barely represent any serious hindrance.

These two types do not cause problems. Quite interesting, however, are those who do represent a difficulty, which are the following two types:

3. Short-term losers who become long-term winners: they give rise to the political problem of bridging.

4. Short-term and long-term losers: they represent the problem of compensation.

A problem typical for processes of modernisation and transformation in society is that the bearers of the short-term costs tend to hinder development in society that could in the long run be to the advantage of all. Participation in the globalisation process in particular can be jeopardised by short-term losers, and hence the society as a whole could miss out on its long-term benefits. Consequently, successful participation in the globalisation process depends crucially on the presumable losers, and on their potential and willingness to oppose it. I will therefore concentrate on types 3 and 4, indicated above, because they are the potential source of the threat to globalisation. The key question is how can the costs relating to globalisation be made bearable and something be offered to the presumable losers.

There are several telling examples for (presumable) losers opposing globalisation. Bismarck's Schutzzollpolitik in Germany is a historical case in point. The period of Liberalism ended with the beginning of the Great Depression [Rosenberg 1967]. The claim for the introduction of customs came primarily from the old-fashioned parts of the economy, which were threatened by the world markets, in order to pro- 
tect themselves. German agriculture became disconnected from transnational competition and hence could afford to let the modernisation-gap continue to grow. Deficits of rationalisation and high food prices were the collective damage that resulted.

The German case shows also that the politics of national protection against world markets is what triggered the establishing of business associations. The main aim of the German business associations that were founded at the end of the 19th century was the implementation of protective tariffs [cf. Ullmann 1988: 77f.]. The name of the top association, founded in 1876, designated its programme 'Centralverband deutscher Industrieller zur Beförderung und Wahrung nationaler Arbeit' [Ullmann 1988: 78].

The main concern was protecting the interests of those branches of the economy (the coal and iron industries, the textile industry), which saw themselves as the potential losers in international competition. These interests were embedded in coalitions of employers and employees on a national basis.

The same pattern of conflict can be found in the negotiations of the NAFTA treaty. NAFTA was supported in the United States by the export-oriented modern branches of the economy and opposed by those in fear of being defeated in the competition with Mexican firms [cf. Bolle 1993; Belous and Lemco 1995]. Without coalitions between employers and employees emerging out of this process, the losers' branches would never have had any political influence. It was the poorly educated urban under-classes, already disadvantaged in the labour market, which opposed NAFTA most intensely. Their fears were taken up by Ross Perot, running for the presidency at the time, and integrated into his aggressive, isolationist community rhetoric. He affected to hear the 'giant sucking sound' [Perot 1993] of jobs disappearing in the direction of Mexico. ${ }^{2}$

These days, in 2004, isolationist tendencies are again gaining ground. In the United States, there is a broad debate centring on the issue of 'offshoring', i.e. the job shifting caused by firms outsourcing to low-wage countries like India. Also, polls show significantly declining approval rates on matters of free trade. The US Senate has passed a regulation aimed at impeding the offshoring of IT jobs. In addition, there are proposals for excluding firms producing a part of their offers outside the US from receiving public orders [cf. Zürcher Zeitung, 13, 14 March 2004, p. 15; Financial Times Deutschland 24 March 2004, p. 4].

It is evident that as world society develops from a humanistic vision into reality, there is an increasing awareness that participating in the globalisation process comes with costs. In order to avoid these costs the presumable losers are likely to oppose all political decisions that result in an intensification of participation in international competition. Thus, for these people the nation-state has become a bulwark against globalisation.

\footnotetext{
2 See also the story of the victims and winners in the transfer of jobs from Lower Bavaria to China [Süddeutsche Zeitung 27 August 2003].
} 
To make a brief and provisional summary, globalisation causes gains and losses, hence spawning the opposition against it. The present globalisation process has historical precedents, it has been and will continue to be triggered by politics, and it depends on social preconditions. This result challenges the public construction that there exists a contradiction between globalisation and the welfare state.

Of course, there have been contributions to this discussion which have pointed out one or another of these very features. Globalisation has been put into a longterm historical context [cf. Borchardt 2001; Robertson 2003], arguments have been collected that refute the thesis of the powerless state [cf. Cerny 1996; Weiss 1998] and support the thesis of globalisation's social preconditions [cf. Rodrik 1997; Rieger and Leibfried 2003; Vobruba 2001], and attempts have been made to conceptualise globalisation as a social construction [cf. Seeleib-Kaiser 2002; Jordan 1998; Schmidt 2002]. ${ }^{3}$ But in comparison with the immense body of economic literature, and with the insistence transnational elites put on the contradiction between globalisation and national welfare states, these contributions remain exceptions. And what is more, criticism to date has barely led to any research that would re-conceptualise globalisation.

\section{The need for social policy}

For the purpose of the following discussion, I have excluded the possibility that national elites engaged in promoting the participation of their respective country in globalisation can overcome the resistance put up by the presumable losers through non-democratic means. Therefore, the next question is how the losers in globalisation could effectively veto participation in the globalisation process. Within democratic systems capital interests can hardly prevail alone. The political importance of the globalisation-losers derives from coalitions of employers and employees within loser-branches. These coalitions emerge on the basis of the common interest of capital and labour to maintain 'their' firm. This is the reason why representatives of business interests call for protectionism in the name of protection for national labour ('Schutz der nationalen Arbeit'). The importance of social policy for rendering participation in the globalisation process feasible is immediately clear. But what are the underlying mechanisms that make social policy a precondition for successful participation in the globalisation process?

The chances to carry through protectionism are based on the fact that workers are dependent on their jobs. Their dependency is as higher, as they are without any alternative for making their living, and hence are forced to oppose globalisation in coalitions with their firms. When this happens, then any room for political ma-

\footnotetext{
${ }^{3}$ As far as I know, there is still no longitudinal analysis of public perceptions of globalisation, and thus no empirical knowledge about its development. The most elaborate reseach in a cross-national perspective is in Seeleib-Kaiser [2001; 2002].
} 
noeuvring against claims for protectionism can only be based on institutions that mitigate the workers' dependency on their jobs.

There is a theoretical argument about the additional use of social policy, which shows that a classic effect - and potentially even a task - of social policy is that of buffering the negative consequences of the processes of modernisation [cf. Vobruba 1996]. Within the theoretical framework of system theory it has been argued that social policy enforces functional differentiation. In particular, it enables the economic system to focus exclusively on efficient production by shielding it from social requirements [cf. Huf 1998]. From the perspective of the theory of action, social policy as a source of income can be viewed as alleviating individual problems of material existence and mitigating the constraints of the labour market [cf. Vobruba 1991]. Consequently, politics that (at least temporarily) endanger jobs can ameliorate their chances of being tolerated if they (as well as the people involved) are able to rely on social policy [cf. Nissen 1994; Vobruba 2003]. The perspective of the additional use of social policy points to the hypothesis that the success of the political decision to participate in the globalisation process depends on a country's ability to compensate for the costs with social policy. More precisely, the presumable losers in the globalisation process must be able to foresee that their welfare state will provide them with some form of compensation. Historical examples [cf. Rieger and Leibfried 2003] and empirical evidence from international comparative research [cf. Graham 1994] render this hypothesis at least somewhat plausible. It is therefore possible to conclude that social policy adds to the chances of the present process of globalisation being successful and sustainable.

Until now I have been compiling arguments in favour of the thesis that governments need to back their decision to participate in the globalisation process with social policy. But this by no means contributes to clarifying the question of whether they are able to do so. After all, the predominant assumption is that globalisation deprives national welfare states of their material basis [cf. Wilding 1997]. Hence the dilemma of globalisation can be precisely formulated: social policy is one of the preconditions for globalisation, but globalisation undermines national welfare states [cf. Vobruba 2001].

\section{The way out of the globalisation dilemma}

In the history of Europe in the 20th century there is empirical evidence that, contrary to the current common view, globalisation and the development of modern welfare states can - in Europe at least - co-exist. The developments of both show some remarkable similarities. The modern European welfare states began to evolve in the last decades of the 19th century and in the early 20th century. After the end of the First World War the development of European welfare states stagnated at the level they had reached up until that point. During the world economic crisis some dismantling of the welfare states took place, varying in degree from country to country. Not un- 
til the end of the Second World War did a new phase of expansion occur. The full maturity of the European welfare states is a result of the 1950s and 1960s. Over the past decade the development of the welfare states has stagnated. But, notwithstanding some exceptions, like New Zealand, prognoses about the 'dismantling of the welfare state(s)' [Pierson 1994; cf. Borchert 1996] have been highly exaggerated.

The development of globalisation reveals a surprisingly similar pattern. Within the decades before the First World War there was a rapid increase in international entanglements. The period between the wars experienced a remarkable setback, and then, in the 1950s, globalisation increased again. From that time globalisation was on an upward trend. Finally - not unlike the development of the welfare states - the upward trend flattened out over recent years.

Of course, the observation of parallels in the development of the European welfare states and globalisation only proves that there is no systematic incompatibility between them. In order to show whether the present globalisation dilemma can be solved, a theoretical argument is required.

Is there a way out of the globalisation dilemma? The statement that globalisation destabilises national welfare states renders it necessary to indicate how globalisation affects welfare states. Generally speaking, a welfare state is stable if there is a balance between the resources it can attract and the demands it has to cope with. Its resources consist of contributions and/or taxes, while the demands it faces stem from the level of socio-political payments and the number of cases it is responsible for. Thus the question of how globalisation affects national welfare states can be split into two more concrete questions [cf. Ganssmann 2000: 151ff.]:

1. Is globalisation likely to erode the material basis of national welfare states?

2. Is globalisation likely to cause additional social problems, which the national welfare states are responsible for?

Ad 1. Generally speaking, participation in the globalisation process triggers economic growth. This at least is the basic argument for globalisation. Therefore, ceteris paribus, one must conclude that in the course of globalisation a country's yield in taxes and contributions will increase. Certainly an objection could be made that this ceteris paribus assumption is unrealistic. It might be stated that national governments are forced by economic globalisation to reduce taxes and contributions. This is a common objection, especially with respect to those cases where the large majority of taxes and contributions are closely tied to wages, causing high non-wage labour costs and thus damaging international competitiveness in comparison with low-wage economies.

But this objection is tenuous in a two ways. First, the problem of competition between high and low-wage economies only exists to a limited degree. This is because globalisation almost exclusively affects the rich, high-wage economies. The overwhelming share of the FDI-flow moves from high-wage economies into highwage economies. Furthermore, at present firms are increasingly hesitant about, if not actually turning away from, investing into cheaper regions in the world. This is evidence of the serious locational disadvantages of low-wage countries. While they 
can indeed offer cheap labour, they offer neither skilled workers nor sufficient and suitable non-monetary conditions for production. This is true for several former Soviet states and even more so for Africa. The high productivity rates in high-wage economies compensate by far for the high-wage and wage-related costs. Thus by comparing costs per unit - and that's exactly what counts - high-wage economies are thoroughly capable of competing. For instance, in Germany and Austria wage and non-wage labour costs are high, but within recent years their labour costs per unit have steadily decreased (Sachverständigenrat 1998/1999: 33), thus securing their international competitiveness. In contrast to the broad debate on Germany's international competitiveness, and despite the strong EURO, the German economy has experienced a steady growth in exports (Sachverständigenrat 2002/2003: 93). Year after year Germany appears as the 'world-champion' in exports.

All in all, globalisation has only little impact on the resources of national welfare states. But it certainly is possible that political misperceptions of the impact of globalisation lead to problems. But it is difficult to distinguish a case of this kind from the possibility that, by referring to the alleged coercions caused by globalisation, special interests are being pursued against the welfare states. With respect to the public perception of economic globalisation both cases result in the same end: They contribute to the construction of a contradiction between globalisation and the welfare state.

Ad 2. Is globalisation likely to cause additional social problems, which are the responsibility of the welfare state? The most expensive parts of modern welfare states, old age pensions and health security systems, develop almost independently of economic globalisation. ${ }^{4}$ But globalisation has a direct impact on labour markets, hence affecting unemployment insurance systems. This consideration demonstrates the restricted realm of the possible consequences of globalisation for expenditures in the national welfare state.

Changes in export/import-relations and foreign direct investments are likely to trigger changes in the international division of labour, and these changes may in turn have an impact on national labour markets, contributing to the changes in the demand for labour. In addition, changes on the supply-side of the labour market could be caused by trans-national migration. Both effects are likely to cause additional unemployment.

At this stage of the discussion it is clear that the labour market is the link between globalisation and the welfare states. Globalisation's impact on the welfare states unfolds via the national labour markets [cf. Martin 1997]. It is primarily rapid changes in the international division of labour that could cause the demand for labour to shrink in the national labour market. But even if the level of total labour

\footnotetext{
${ }^{4}$ At least in Germany the liberal-conservative discourse directed against the welfare state has switched from globalisation to the ageing society as the main threat to the welfare state [cf. Walter 2003]. My assessment of this shift is that it represents implicit acknowledgement of the minor impact globalisation has on the European welfare states.
} 
demand remains stable, globalisation could lead to irreversible losses of jobs in several branches.

This takes us back to the two crucial types of participants in globalisationfaiths: Short-term losers who are long-term winners, and short- and long-term losers.

\section{Bridging and compensating}

At least in the short run, participating in the globalisation process is the result of political decisions. The acceptance of such decisions crucially depends on the way in which the potential losers in globalisation and their political veto-power are dealt with. On the one hand, the welfare state can support the acceptability of participating in the globalisation process. On the other hand, however, globalisation does not support the stability of welfare states. This exactly is the globalisation-dilemma: Globalisation requires the backing of the welfare state, at the same time as it undermines it. But this dilemma is by no means unsolvable. Normally the negative impact of globalisation on the national welfare states is highly overestimated. Globalisation barely affects the welfare state's resources and its negative impact is concentrated in the area of social problems related to labour markets. In sum, the financial manoeuvring space is stable and the increase in the amount of socio-political problems is limited.

How can the problems be dealt with? For the two types of losers in globalisation - 'short-term losers who become long-term winners' and 'short-term and longterm losers' - I would introduce a distinction between two basic types of welfare state strategies.

1. Bridging: In this case the problem is maintaining labour power for re-entry into the labour market plus cultivating its qualifications.

2. Compensating: This means offering alternatives to the labour market. This could result in unrestricted access to social transfers, or access to income from capital, or both.

\section{Bridging.}

Among the losers in the globalisation process there are the many unemployed who can realistically expect future opportunities in the labour market. In these cases, socio-political measures aimed at helping to maintain an orientation towards the labour market and support the ability to work are appropriate. For the 'short-term losers but long-term winners' type, the adequate measures are social payments that at least fairly secure the status of income, support willingness to work and offer further training. In other words, social policy centred on wage labour is best suited to these types of problems. 


\section{Compensating}

Those who are short- and long-term losers bear the brunt of the social costs of globalisation. If it is true that participating in globalisation generally causes gains in welfare, but parts of the population are excluded from direct access to these gains via the labour market, than other mechanisms are required in order to give them a share in the welfare gains. As I have tried to argue, this is not just a question of passionate regard, but could also turn out to be a precondition for the acceptance and thus for the feasibility of globalisation itself.

All forms of social policy centred on wage-labour, which keep people in a waiting position close to the labour market, are inappropriate for the short- and longterm losers in the globalisation. It makes no sense to force permanently excluded people to orient themselves towards dependent work. It is instead important to offer them alternatives to the labour market. Thus the questions about other income sources and about how to regulate them and how to further them become relevant. In modern societies, which are fully based on money, there clearly are a limited number of sources of income. Agriculture has lost its function as an autonomous source of income and as a possibility of retreat for the unemployed. Worldwide rapid urbanisation is destroying the basis for all sorts of income in kind. Three sources of income in cash remain: the labour market, capital and the welfare state. One might imagine various 'income mixes' [Vobruba 1998] comprised of these three types of income. Incomes from capital and from welfare-state payments can be seen as compensation for wage losses caused by globalisation. The idea of compensating the losers in globalisation via the welfare state relates to the basic income discussion and especially to the idea of a negative income tax. A negative income tax enables legal combinations of socio-political payments with other kinds of income. Political support for capital incomes as compensation relates to the idea of the 'share economy' [Meade 1986], which could be adopted into the discourse on globalisation. The underlying consideration is that the gains engendered by globalisation that emerge as profits should be distributed through enlarged participation in capital earnings, hence compensating for at least a portion of wage losses.

\section{Some conclusions}

I will limit myself to three remarks. The public discourse on globalisation increasingly focuses on the losers. Globalisation is dominantly seen as the main cause for rising inequalities between the first and the third world as well as within individual countries [cf. Wade 2003]. In Europe, the political construction of the relationship between globalisation and national welfare states has experienced a remarkable change. Years ago, globalisation was perceived as a material constraint and the cutting back of the welfare state as its unavoidable consequence. Be it pure economic ideology, or a political strategy of blame avoidance, or even true convictions, a neg- 
ative nexus between globalisation and social security was established [cf. Watson and Hay 2003]. Globalisation is unavoidable - so forget the welfare state! Nowadays this nexus still persists, but its political impact has changed, as the public perception of globalisation as an economic constraint turns into an understanding of it as resulting from political decisions: If more globalisation means more inequality and less social security - then drop globalisation!

There are good reasons to assume that in the long run economic globalisation is likely to cause gains for (almost) all. At least there is strong historical evidence that the withdrawal of globalisation, as happened between the two world wars, is extremely costly [cf. Robertson 2003: 152ff.]. But notwithstanding this fact, in the short term, the dangers posed by globalisation dominate in the public attitudes against it. As relevant groups within society perceive economic globalisation as an existential treat, it is all the more likely that they will tend to try to hinder globalisation. Social policy plays a crucial role in partially absorbing those dangers, hence making the short-term horizon of people's interests and the longer-term horizon of globalisation compatible, and thus protecting globalisation by buffering it. In this perspective - and in contrast to the common wisdom - the European Social Model, with its built-in long-term perspective, turns out to be well equipped for coping with globalisation.

Globalisation and national welfare states - the core of the European Social Model - may be viewed as mutually supportive. Globalisation yields additional economic growth, hence compatibility with the welfare state must be a matter of distribution. And social policy paves the way for the public acceptance and thus for the success of globalisation under democratic roles. Consequently, by providing the national welfare states with enough financial resources globalisation secures its own sustainability.

But this relationship also has the potential to work the other way around: If relevant actors think that globalisation will destroy the welfare state, then indeed it has this impact. Welfare state retrenchment, publicly justified by globalisation, is likely to lead to resistance against globalisation, diminishing its economic potential, hence causing reasons for further cutting back on the welfare state. In this case globalisation really endangers the national welfare states. But then - as I have tried to demonstrate - globalisation becomes endangered, too.

GEORG VOBRUBA is a professor of sociology at the University of Leipzig. His current fields of research include the labour market and social policy, European integration, and globalisation. His most recent books are Integration + Erweiterung. Europa im Globalisierungsdilemma; Wer sitzt in der Armutsfalle? Selbstbehauptung zwischen Sozialhilfe und Arbeitsmarkt (together with Ronald Gebauer and Hanna Petschauer); and Die Entwicklung sozialer Wirklichkeit (co-edited with Nikos Psarros and Pirmin StekelerWeithofer). 


\section{References}

Belous, Richard and Jonathan Lemco (eds.). 1995. NAFTA as a Model of Development. The Benefits and Costs of Merging High-and Low-Wages Areas. Albany: State University of New York Press.

Bolle, Mary Jane. 1993. NAFTA: U.S. Employment and Wage Effects. CRS Report for Congress. Congressional Research Service. The Library of Congress.

Borchardt, Knut. 2001. "Globalisierung in historischer Perspektive." Sitzungsberichte. München: Bayrische Akademie der Wissenschaften, Philosophisch-historische Klasse: 3-34.

Borchert, Jens. 1995. Die konservative Transformation des Wohlfahrtsstaates. Frankfurt: Campus.

Bright, Charles and Michael Geyer. 1994. "Globalgeschichte und Einheit der Welt im 20. Jahrhundert." Comparativ 4 (5): Leipzig: 13-45.

Cerny, Philip G. 1996. "What Next for the State?" Pp. 123-137 in Globalization. Theory and Practice, edited by Eleonore Kofman and Gillian Youngs. London, New York: Pinter.

Ganssmann, Heiner. 2000. Politische Ökonomie des Sozialstaats. Münster: Verlag Westfälisches Dampfboot.

Giddens, Anthony. 1990. The Consequences of Modernity. Stanford: Stanford University Press.

Gough, Ian. 1997. "Social Aspects of the European Model and Its Economic Consequences." Pp. 79-96 in The Social Quality of Europe, edited by Wolfgang Beck, Laurent van der Maesen and Alan Walker. Doordrecht: Kluwer Law International.

Graham, Carol. 1994. Safety Nets, Politics, and the Poor. Transitions to Market Economies. Washington, D.C.: The Brookings Institution.

Held, David, Anthony G. McGrew, David Goldblatt and Jonathan Perraton. 1999. Global Transformations. Cambridge: Polity Press.

Held, David and Mathias Koenig-Achibugi (eds.) 2003. Taming Globalization. Frontiers of Governance. Cambridge: Polity Press.

Hirst, Paul and Grahame Thompson 1996. Globalization in Question. Cambridge: Polity Press.

Huber, Evelyne and John D. Stevens. 2001. Development and Crisis of the Welfare State. Chicago, London: The University of Chicago Press.

Huf, Stefan. 1998. Sozialstaat und Moderne. Modernisierungseffekte staatlicher Sozialpolitik. Berlin: Duncker \& Humblot.

International Monetary Fund. 1997. World Economic Outlook. May 1997. Washington, D.C.: International Monetary Fund.

Jordan, Bill. 1998. The New Politics of Welfare. London: SAGE.

Kant, Immanuel. 1912-23. "Idee zu einer allgemeinen Geschichte in weltbürgerlicher Absicht." In Akademie-Ausgabe, Bd. VIII. Berlin: Walter de Gruyter.

Keohane, Robert O. 2003. "Global Governance and Democratic Accountability." Pp. 130-159 in Taming Globalization. Frontiers of Governance, edited by David Held and Mathias Koenig-Archibugi. Cambridge: Polity Press.

Martin, Andrew. 1997. "What Does Globalization Have to Do With the Erosion of Welfare States? Sorting Out the Issues." ZeS-Arbeitspapier Nr. 1. Bremen: Zentrum für Sozialpolitik.

Meade, James. 1986. Different Forms of Share Economy. London: Public Policy Centre.

Nissen, Sylke. 1994. "Arbeitsplatzangst und politischer Immobilismus." Zeitschrift für Sozialreform 40 (12): 781-796.

Nofal, María Beatriz. 1995. "The Economic Integration of Argentina and Brazil, MERCOSUR, and the Regionalization of the Southern Cone Market." Pp. 203-230 in 
NAFTA and Trade Liberalization in the Americas, edited by Elise Echeverri-Carroll. Austin: Bureau of Business Serearch.

Norberg, Johan. 2003. In Defense of Global Capitalism. Washington, D.C.: Cato Institute.

Notes from Nowhere (ed.). 2003. We Are Everywhere. The Irresistible Rise of Global Anticapitalism. London: Verso.

Perot, Ross. 1993. Not for Sale at Any Price. New York: Hyperion Books.

Pierson, Paul. 1994. Dismantling the Welfare State? Cambridge: Cambridge University Press.

Rieger, Elmar and Stephan Leibfried. 2003. Limits to Globalization. Welfare States and the World Market. Cambridge: Cambridge University Press.

Robertson, Robbie. 2003. The Three Waves of Globalization. London, New York: Zed Books.

Roddick, Anita. 2001. Take It Personally. How Globalization Affects You and Powerful Ways to Challenge It. London: HarperCollins Publishers.

Rodrik, Dani. 1997. Has Globalization Gone Too Far? Washington, D.C.: Institute for International Economics.

Rosenberg, Hans. 1967. Große Depression und Bismarckzeit. Frankfurt: Ullstein.

Sachverständigenrat 1998/1999. Jahresgutachten 1998/1999 des Sachverständigenrates zur Begutachtung der gesamtwirtschaftlichen Entwicklung. Bundestag Drucksache.

Sachverständigenrat 2002/2003. Jahresgutachten 2002/2003 des Sachverständigenrates zur Begutachtung der gesamtwirtschaftlichen Entwicklung. Bundestag Drucksache.

Schmidt Vivienne A. 2002. The Futures of European Capitalism. Oxford: Oxford University Press.

Seeleib-Kaiser, Martin. 2001. Globalisierung und Sozialpolitik. Ein Vergleich der Diskurse und Wohlfahrtssysteme in Deutschland, Japan und den USA. Frankfurt: Campus.

Seeleib-Kaiser, Martin. 2002. "Globalization, Political Discourse, and Welfare Systems in a Comparative Perspective: Germany, Japan, and the USA." Czech Sociological Review 38 (6): 749-770.

Stiglitz, Joseph. 2002. Globalization and its Discontents. London: Penguin Books.

Strange, Susan. 1996. The Retreat of the State. New York: Cambridge University Press.

Therborn, Göran. 2001. "Globalization and Inequality. Issues of Conceptualization and Explanation." Soziale Welt 52 (4): 449-476.

Ullmann, Hans-Peter. 1988. Interessenverbände in Deutschland. Frankfurt: Suhrkamp.

Vaughan-Whitehead, Daniel. 2003. EU Enlargement versus Social Europe? Cheltenham: Edward Elgar.

Vobruba, Georg. 1991. Jenseits der sozialen Fragen. Frankfurt. Suhrkamp.

Vobruba, Georg. 1996. “The Additional Use of Social Policy in the Modernization and Transformation of Societies." Pp. 161-173 in Changing Europe, edited by Angus Erskine. Aldershot: Avebury.

Vobruba, Georg. 1997. "Social Policy for Europe." Pp. 105-120 in The Social Quality of Europe, edited by Wolfgang Beck, Laurent van der Maesen and Alan Walker. Doordrecht: Kluwer Law International.

Vobruba, Georg. 1998. "Income Mixes. Work and Income Beyond Full Employment." Crime, Law and Social Change 29 (1): 67-78.

Vobruba, Georg. 2001. Integration + Erweiterung. Europa im Globalisierungsdilemma. Wien: Passagen.

Vobruba, Georg. 2003. “Die sozialpolitische Selbstermöglichung von Politik." Pp. 383-397 in Der Begriff des Politischen. Sonderband 14 der Sozialen Welt, edited by Armin Nassehi and Wolfgang Schroer. Baden-Baden: Nomos. 
Wade, Robert Hunter. 2003. “The Disturbing Rise in Poverty and Inequality: Is It All a 'Big Lie'?" Pp. 18-46 in Taming Globalization, edited by David Held and Mathias Koenig-Archibugi. Cambridge: Polity Press.

Watson, Matthew and Colin Hay. 2003. "The Discourse of Globalization and the Logic of No Alternative: Rendering the Continent Necessary in the Political Economy of New Labour." Policy \& Politics 31 (3): 289-305.

Weiss, Linda. 1998. The Myth of the Powerless State. Ithaka, N.Y.: Cornell University Press.

Wilding, Paul. 1997. "Globalization, Regionalism and Social Policy." Social Policy $\mathcal{E}$ Administration 31 (4): pp. 410-428.

World Bank. 2002. Making Trade Work for the Poor. Washington, D.C.: World Bank.

Yeates, Nicola. 2001. Globalization and Social Policy. London: SAGE. 